\title{
Design and Adaptation of a Commercial Cold Storage Room for Umudike Community and Environs
}

\author{
Ugwu, Hyginus Ubabuike*, Ogbonnaya, Ezenwa Alfred \\ Department of Mechanical Engineering, Michael Okpara University of Agriculture, Umudike, \\ P.M.B. 7267, Umuahia, Abia State, Nigeria
}

\begin{abstract}
A cold storage room for Umudike has been designed to provide a better storage facility for perishable food stuff in the community and to promote the living standard of the people. It is an adaptive design aimed at designing the cold room to suit the prevailing factors of Umudike community with reference to some design calculations. This is timely, and a first of its kind within the locality. The design complies with all standard refrigeration principles and theory to best suit the prevalent climatic condition in Umudike. This design is hypothetically intended to serve as a guide for future fabrication and erection. The cold room has an estimated total refrigeration capacity of $0.82 \mathrm{TR}$ (about 4Hp), and a maximum COP of 6.09. Its operating ambient temperature is $36^{\circ} \mathrm{C}$ with a rated evaporator capacity of $1.85 \mathrm{Hp}$ and a rated condenser capacity of $2.15 \mathrm{Hp}$, respectively. In practice, the cold room will operate for 24 hours daily and will provide storage for agricultural produce and dairy products. The cold room is expected to serve and provide the demand of the people of Umudike and her environs for a period of ten years before a complete overhaul. The unit cost of the facility is put at eight hundred and twenty two thousand, five hundred and fourteen naira, and fiftyfive ( $\$ 822$, 514.55) kobo only. The cold room if erected as designed inevitably will enhance the living standard of the community by providing them the access to fresh foods and dairy products. It will also improve the local economy of the community by increasing the gross domestic product through better preservation, and tremendously reduce the frequency of them going to the farm for harvest.
\end{abstract}

Keywords: - Commercially adaptive design, Cold storage room, Umudike community and environs, First of its kind, Prevailing climatic condition and factors, Enhancing living standard and local economy of the community

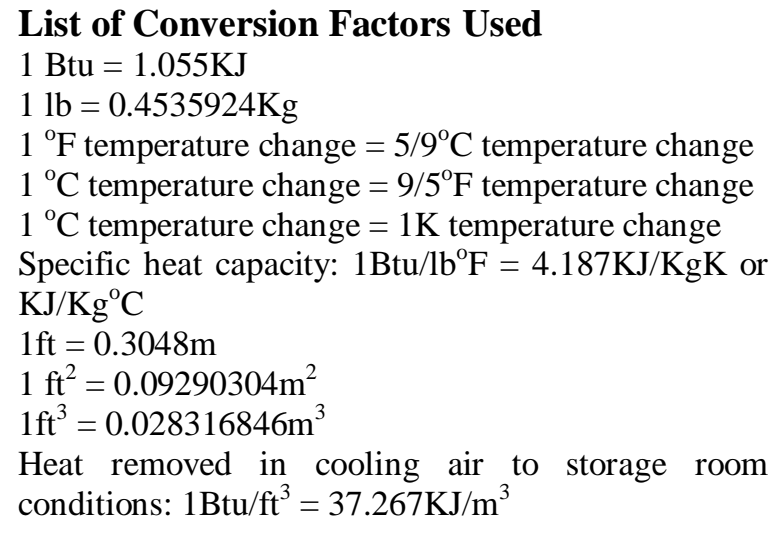

Temperature unit conversions:

$\mathrm{X}^{\circ} \mathrm{C}=5 / 9\left(\mathrm{Y}^{\circ} \mathrm{F}-32\right)$

$\mathrm{Y}^{0} \mathrm{~F}=\left(9 / 5 \times \mathrm{X}^{0} \mathrm{C}\right)+32$

$\mathrm{ZK}=\mathrm{X}^{\circ} \mathrm{C}+273$

$\mathrm{X}^{\circ} \mathrm{C}=\mathrm{ZK}-273$

where: $\mathrm{X}=$ Temperature in Celsius, $\mathrm{Y}=$ Temperature in degree Fahrenheit, and $\mathrm{Z}=$ Temperature in Kelvin.

Respiration heat load: $1 \mathrm{Btu} / 16$ per day $=2.326 \mathrm{KJ} / \mathrm{kg}$ per day

Heat released per occupant: $1 \mathrm{Btu} / \mathrm{hr}=1.055 \mathrm{KJ} / \mathrm{hr}$

Connected load in refrigerated space: $1 \mathrm{Btu} / \mathrm{HP} \mathrm{hr}=$ $1.415 \mathrm{KJ} / \mathrm{KWhr}$

Motor Horsepower: $1 \mathrm{Hp}=0.7457 \mathrm{KW}$

Insulation thickness: $1 \mathrm{in}=2.54 \mathrm{~cm}=0.0254 \mathrm{~m}$

Heat gain factors: $1 \mathrm{Btu} / \mathrm{Ft}^{2} 24 \mathrm{hr}=11.356 \mathrm{KJ} / \mathrm{m}^{2}$ day

$$
\begin{aligned}
& \text { Latent heat: } 1 \mathrm{Btu} / \mathrm{b}=2.326 \mathrm{KJ} / \mathrm{kg} \\
& 14.7 \mathrm{lb} / \mathrm{m}^{2}(14.7 \mathrm{Psia})=101.3 \mathrm{Kpa}\left(101.3 \mathrm{~N} / \mathrm{m}^{2}\right) \\
& 1 \mathrm{ft}^{3} / \mathrm{lb}=0.0624 \mathrm{~m}^{3} / \mathrm{Kg}
\end{aligned}
$$

\section{INTRODUCTION}

A personal survey conducted in Umudike locality and environs, reveals that no development such as cold storage has been found in Umudike community whereas the level of food crops production, commercial and industrial activities in the community demand that at least one, should be provided. The necessity primarily prompted the essentiality of this study.

The study also points out that the principle of refrigeration as studied in the classroom would not only remain in theory, but can be made tangible in typical practical application in order to be fully, faithfully and amply appreciated.

Moreso, since most cold rooms are designed and manufactured away from out tropical area, they cannot function at their maximum full and optimal capacity in our environment. This design thus, was carried out without any climatic conditions and environmental settings in mind. With the actualization of this Unit through physical construction and erection, the people of Umudike 
will heave and breathe a sigh of relief. Thus, the importance of this design and its full implementation cannot be over emphasized or underestimated.

Refrigeration is the process of removing heat from a substance under controlled conditions [1]. Refrigeration uses the evaporation of a liquid to absorb heat. Before mechanical refrigeration systems were introduced, people cooled their food with ice and snow, either found locally or brought down from the mountains. The first cellars were holes dug into the ground and lined with wood or straw and packed with snow and ice. This was the only means of refrigeration for most of history.

All the foods utilized by man are obtained either from plants or animal kingdom. Most of these foods are not produced in a whole year. They are produced at different places in a particular season especially when it involves much technicalities to produce them. Also, some of these foods are imported, since some of them are required all round the year in various parts of the country. Thus, it becomes very essential and imperative to preserve them during transportation and subsequent storage until they are finally consumed.

Cold room storage generally tends to depict the views and ideas of a system that embarks on a continual extraction of heat from its body whose temperature is already below its surrounding temperature. Thus, refrigeration inevitably is the only means of preserving food in its original freshness.

The refrigeration industry became important commercially during the $18^{\text {th }}$ century [2]. Early refrigeration as the source reported, was obtained by use of ice which usually were cut from lakes and ponds and stored in the winter in insulated store rooms for summer use. Nowadays, different modern refrigeration systems existing in the market today went through various modifications since the inception of the early ones, as reviewed and documented by other different scientists and researchers [2-6].

With respect to refrigerant, research and development are resulting in some additional substitutes, such as R507 and R404A as replacement for R502 and HCFC22 which are widely used in the United States and other parts of the world. These also, are the predominant refrigerants used in screw, scroll and reciprocating equipment. Presently, in virtually all unitary equipment these days, R134a, R407C and $\mathrm{R} 410 \mathrm{~A}$, etc serve as potential replacements of such refrigerants [6]. Basically, a cold room like refrigerators and air-conditioners utilizing these refrigerants as their working fluids consists principally of different integrated components which uniquely work in alliance with other auxiliary equipment to achieve the required cooling.

\section{I.1 Statement of Problem and Need for the Study}

The idea of thought for any project is instigated on the curiosity to satisfy a need at hand. Umudike community located $25 \mathrm{~km}$ from Umuahia metropolis in Abia state, Nigeria is a strategic community of wide acclaim and fame. The community accommodates the National Root Crops Research Institute, Umudike (NRCRI); The Michael Okpara University of Agriculture, Umudike (MOUAU); and the host village: Umudike autonomous community. These three communities with their unique characteristics occupy different part of the Umudike land area. A survey conducted in Umudike community [7] shows that the prolonged lack of adequate and sizeable modern preservation facilities such as a cold room has brought untold hardship both economically and socially to the people. The associated population densities of the three communities which are uniquely positioned and contiguously demarcated aided in determining the size of the cold room.

The people of Umudike, a community in Ikwuano Local Government Area of Abia State with a population figure of 137,993 in 2006 Population census [7] has an estimated annual growth rate of $3.6 \%$. This increased their current population figure to 142,960 during the 2007 population projection. Umudike is traditionally and predominantly a farming community whose major agricultural products include arable crops, cereals, vegetables, palm produce and livestock, etc. These in fact, necessitated the institutionalization of the NRCRI and the MOUAU to the host community in Umudike.

In the same vein, MOUAU presents its most variable population because it is a growing Federal University Campus. With an estimated growth rate of $30 \%$ in students' population, the current students' population density is estimated at 11,989 , while the staff 
population is estimated at 3,386 [8]. Conversely, NRCRI being a research Institute has an almost fixed number of resident and non-resident staff on annual basis. Each resident of staff lives with an average family of four, with a population of 200 resident staff. Thus, the total resident population is estimated at 800 , while non-resident staff population is estimated at 300 , which consequently, brings the total active population of the Institute to 1100 with an estimated growth rate of $0.6 \%$ [9-10].

A detailed survey of the agricultural output from the communities identifies that:

- NRCRI is renowned for root crops, poultry, domestic dairy products, and meat production, etc; while

- MOUAU is famous in food crops production, and processing of dairy products (meats, fish, poultry, rabbitry, snailry, piggery, etc) and

- UMUDIKE villagers (the host community), are well established in subsistence farming products, domestic animal husbandry, cocoa propagation, livestock production, etc.

Presently, no cold room preservation facility whether dilapidated nor obsolete, is functional in the area. Hence, farm produce and dairy products immediately after being harvested are disposed off as quickly as possible to avoid being perished. Thus, it is in accordance and agreement to these enormous livestock, agricultural produces and dairy products obtained in greater quantities in these areas and environs, that the federal government urgently approved the construction of cereal and farm produce storage tank (silos) facility under the Federal Government Food Storage Scheme between Ezinachi and Ugwaku communities both in Okigwe South Local Government Area of Imo State, a distant town from Umudike, near Umuahia city in Abia State. Hence, there is a tremendous need to erect a storage facility such as the cold room in Umudike and her environs from where these economical farm produce and domestic dairy products are sourced to complement the Silos under construction for fresh and perishable farm products and dairy goods. Thus, this was achieved in this study and survey estimates by designing the cold room and allocating some refrigeration loads to the respective communities to serve the current population and future growth. Succinctly, provision of a cold storage room obviously will boost the economic and living standard of the communities since the untold hardship being meted out and unleashed on the host community and her dependents (MOUAU and NRCRI) are highly unsustainable.

\section{I.2 Principles of Operation of a Cold Storage Room}

The cold room like every other refrigerating systems of the same magnitude employs the vapour compression method of mechanical refrigeration [11]. Fig.1 presents the T-s diagram of the vapour compression cycle, while the Fig. 2 illustrates the processes of the refrigeration employed in the cold room, respectively [2].

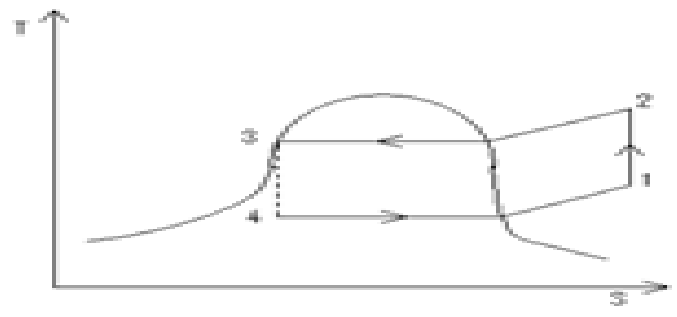

Fig.1: Temperature-entropy diagram of the cold room storage cycle processes

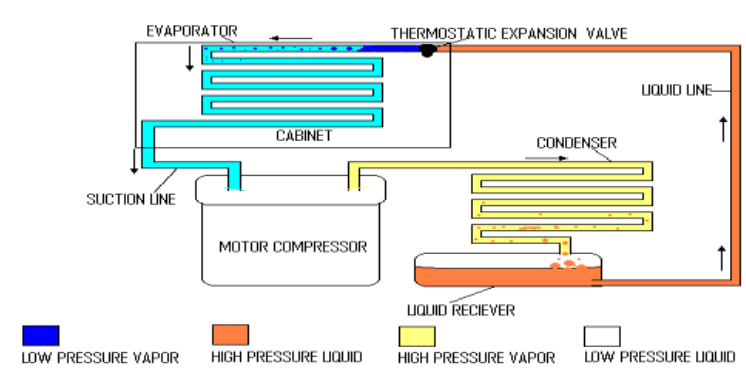

Fig.2: Processes of refrigeration employed in the cold room

\section{DESIGN METHODOLOGY}

\section{II.1 Design Location}

The study area covers Umudike, Umuahia, Abia State. Abia State is located in the South-eastern region of Nigeria and is within latitude $4^{\circ} 40^{\prime}$ and $6^{\circ} 14^{\prime}$ North, and longitude $07^{\circ} 10^{\prime}$ and $08^{\circ} 00^{\prime}$ East, while Umudike community is located within latitudes $05^{\circ} 00^{\prime}-05^{\circ} 29^{\prime}$ and longitude $07^{\circ} 00^{\prime}-07^{\circ} 33 \mathrm{E}$, within the rain forest zone [3]. Geologically, Umudike is a 
sedimentary environment of the lignite series or coastal plain sand formations having a drainage pattern system. It is traditionally and predominantly a farming community with an annual mean rainforest of $2116.8 \mathrm{~mm}$. The soil types are rich arable land and the rivers that surround the whole community support agricultural practice immensely [9-10].

Similarly, MOUAU is an agro-based institution within the Umudike area and flanked by the NRCRI. These institutions intensify the drive towards agricultural activities thereby promoting food production through teaching, research and extension services [3]. Westwards, the topography of MOUAU is flat with sporadic hills at greater distance apart. The ridge also marks the water shed between the Cross River basin and the Kwa-Ibo River basin, respectively.

The aforementioned ridge, marks a ragged country with topographic height of not more than $120 \mathrm{~m}$ above sea level, while the western part of the Umuahia-Ikot Ekpene road, the only major federal road that connects the community and her suburbs with other neighbouring States (Akwa-Ibom and Calabar) harbours the northern portion of the property; though, more of a level ground has a topographic height of $140 \mathrm{~m}$ above sea level. This higher ground indicates the presence of a younger formation lying on the lower side.

\section{II.2 The Refrigeration Cycle Processes of the} Cold Room

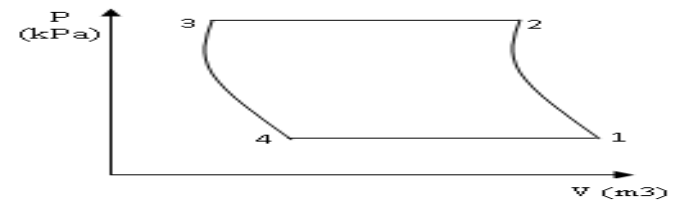

Fig.3 (a): Pressure-volume (P-v) diagram of the process

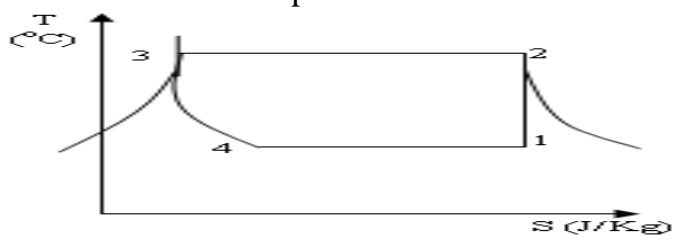

Fig.3 (b): Temperature-entropy (T-s) diagram of the process

The cold room like any other conventional refrigerator has four refrigeration cycle processes.
These, are presented in Figs.3 (a) and (b) that show the P-v and T-s diagrams, respectively [11].

\section{II.3 Heat Load Determination}

The total heat load consists of the amount of heat to be removed from a cabinet during a certain period. It is dependent on two main factors: heat leakage or heat transfer load, and heat usage or service load, respectively. Thus, the following types of heat loads were considered in the design of this cold room:

\section{II.3.1 Heat Leakage Load, $\mathrm{H}_{\mathrm{L}}$}

Heat leakage load or heat transfer load is the total amount of heat that leaks through the walls, windows, ceiling, and floor of the cabinet per unit of time (usually 24 hours). Heat leakage therefore, is affected by the amount of the exposed surface, thickness and the kind of insulation used, and the temperature difference between the inside and the outside of the cabinets. Thus, it is the heat transfer from the outside into the refrigerating space via the insulated wall of the refrigerator. This is given by:

$$
H_{L}=H_{g} \times A_{n}\left(\frac{K J}{24 h r}\right)
$$

where: $\mathrm{H}_{\mathrm{g}}=$ Heat of insulation $\left(\mathrm{m}^{2}\right)$

\section{II.3.2 Heat Usage Load}

The heat usage or service load is the sum of the following heat loads per unit of time (usually 24 hours): Cooling the contents to cabinet temperature, Cooling of air changes, Removing respiration heat from fresh or "live" fish and from meat, Removing heat released by electric lights, electric motors, and the like, and Removing heat given off by people entering and/or working in the cabinet, respectively. Usage or service heat load of the cabinet was determined by the temperature of the articles that were put into the refrigerator, their specific heat, generated heat, and latent heat, as the requirements demanded. Another consideration was the nature of the service required. This involved air changes (determined by the number of times per day that the doors of the refrigerator would be opened) and the heat generated inside by fans, lights, and other electrical devices.

\section{II.3.3 Air Change Heat Load, $\mathrm{H}_{\mathrm{c}}$}


Air that enters a refrigerated space must be cooled. Air has weight and it also contains moisture. When air enters the refrigerated space, heat must be removed from it. Air which entered the refrigerated space usually cools and reduces in pressure. If the cabinet is not air tight, air will continue to leak in. Also, each time a service door or a walk-in door is opened, the cold air inside, being heavier, will spill out the bottom of the opening allowing the warmer room air to move into the cabinet. The actions of moving materials in or out of the cabinet, and a person going in or leaving a cabinet, result in warm air moving into the refrigerated space through the process of infiltration of air. Hence, the Air change heat load is the heat transfer due to opening and closing of the refrigerator doors and subsequent change in air-heat content in the refrigerating space. This is given by:

$$
H_{C}=V \times A_{C} \times H_{m} \quad\left(\frac{K J}{24 h r}\right)
$$

where: $\mathrm{V}=$ Cabinet volume $\left(\mathrm{m}^{3}\right), A_{C}=$ Air changes per $24 \mathrm{hr}$, and $H_{m}=$ Heat per $\mathrm{m}^{3}$. These are presented in Tables 1 and 2, respectively.

\section{II.3.4 Product Heat Load, $\mathrm{H}_{\mathrm{p}}$}

Any substance which is warmer than the refrigerator is placed where it will lose heat until it cools to the refrigerator temperature. Three kinds of heat removal are evident. First, is the specific heat as the ratio of the quantity of heat required to raise the temperature of a body by 1degree to that required to raise the temperature of equal mass of water by 1 degree. This tantamount to the heat given out when a substance generally is being cooled. Others are the latent heat as the heat energy absorbed during the process of changing a substance from its original state to another (either as a result of melting, vaporization, or fusion) without any change in temperature or pressure. In the case of refrigeration, the form of the substance change involved is fusion. Thus, the heat given off as the liquid fuses to ice is known as latent heat of fusion; while the respiration heat is the heat given out as living things, especially plant products give out oxygen and absorb carbondioxide as exhibited in photosynthesis. This is the heat released by the product or food item to be cooled which is given by:

$$
H_{P}=M_{t} x \mathrm{C} \times \mathrm{T}=W_{t} \times \mathrm{C} \times \mathrm{T}
$$

where: $M_{t}=$ Mass or weight of the products (food items) in $\mathrm{kg}, \mathrm{C}=$ Specific heat capacity of products $(\mathrm{KJ} / \mathrm{KgK})$ as documented by [11-13] regarding the temperature, specific heat and latent heat of some common food items, in terms of their Quick freeze temperature, humidity, freezing points and respiration loads, respectively; and $\mathrm{T}=$ Temperature difference between products' room temperature and required cooling temperature $\left({ }^{\circ} \mathrm{C}\right)$.

Table 1: Average Air Changes per 24hours for Storage

(Values took into account door openings and air infiltrations)

\begin{tabular}{|c|c|c|c|c|c|}
\hline S/N & Volume $\left.\mathbf{( m}^{\mathbf{3}}\right)$ & Air Changes Per $\mathbf{2 4} \mathbf{~ H r}$ & $\mathbf{S} / \mathbf{N}$ & Volume $\left.\mathbf{( m}^{\mathbf{3}}\right)$ & Air Changes Per 24 Hr \\
\hline 1 & 5.7 & 44.0 & 13 & 170.0 & 6.5 \\
\hline 2 & 8.5 & 34.5 & 14 & 226.5 & 5.5 \\
\hline 3 & 11.3 & 29.5 & 15 & 283.2 & 4.9 \\
\hline 4 & 14.2 & 26.0 & 16 & 424.8 & 3.9 \\
\hline 5 & 17.0 & 23.0 & 17 & 566.3 & 3.5 \\
\hline 6 & 22.7 & 20.0 & 18 & 707.9 & 3.0 \\
\hline 7 & 28.31 & 17.5 & 19 & 849.5 & 2.7 \\
\hline 8 & 42.5 & 14.0 & 20 & 1132.7 & 2.3 \\
\hline 9 & 56.6 & 12.0 & 21 & 1415.8 & 2.0 \\
\hline 10 & 85.0 & 9.5 & 22 & 2123.8 & 1.6 \\
\hline 11 & 113.3 & 8.2 & 23 & 2831.7 & 1.4 \\
\hline 12 & 141.6 & 7.2 & & & \\
\hline
\end{tabular}

NB: For heavy usage, multiply the above values by 2 ; and for long storage, multiply the values by 0.6 , respectively 
IOSR Journal of Engineering

May. 2012, Vol. 2(5) pp: 1234-1250

Table 2: Chart for Total Heat Removed to Cool Storage Room Air under Varying Conditions of Humidity and Temperature

\begin{tabular}{|c|c|c|c|c|c|c|c|c|}
\hline \multicolumn{9}{|c|}{ Heat removed in cooling air to storage room conditions $\left(\mathrm{KJ} / \mathrm{m}^{3}\right)$} \\
\hline \multirow{4}{*}{$\begin{array}{l}\text { Storage room temperature } \\
\left({ }^{\circ} \mathrm{C}\right)\end{array}$} & \multicolumn{8}{|c|}{ Temperature of outside air $\left({ }^{\circ} \mathrm{C}\right)$} \\
\hline & \multicolumn{2}{|c|}{29} & \multicolumn{2}{|c|}{32} & \multicolumn{2}{|c|}{35} & \multicolumn{2}{|c|}{38} \\
\hline & \multicolumn{8}{|c|}{ Relative humidity (\%) } \\
\hline & 50 & 60 & 50 & 60 & 50 & 60 & 50 & 60 \\
\hline 18 & 24.2 & 31.7 & 34.7 & 43.6 & 46.2 & 57.4 & 58.9 & 72.7 \\
\hline 16 & 31.7 & 38.4 & 42.1 & 51.1 & 53.7 & 64.8 & 66.3 & 80.1 \\
\hline 13 & 41.7 & 50.0 & 52.2 & 61.8 & 64.1 & 75.0 & 76.8 & 90.9 \\
\hline 10 & 49.1 & 57.4 & 60.4 & 69.7 & 72.0 & 82.7 & 85.0 & 98.8 \\
\hline 7 & 56.0 & 64.4 & 67.0 & 76.8 & 79.0 & 90.2 & 92.0 & 106.2 \\
\hline 4 & 63.0 & 71.6 & 74.5 & 84.2 & 86.1 & 97.6 & 99.5 & 114.0 \\
\hline 2 & 69.3 & 77.9 & 80.9 & 90.6 & 92.8 & 104.0 & 106.2 & 120.7 \\
\hline-1 & 74.5 & 83.5 & 84.2 & 94.3 & 98.4 & 109.6 & 110.0 & 124.8 \\
\hline \multirow{4}{*}{$\begin{array}{l}\text { Storage room temperature } \\
\left({ }^{\circ} \mathrm{C}\right)\end{array}$} & \multicolumn{8}{|c|}{ Temperature of outside air $\left({ }^{\mathbf{0}} \mathrm{C}\right)$} \\
\hline & \multicolumn{2}{|c|}{4} & & & \multicolumn{2}{|c|}{32} & \multicolumn{2}{|c|}{38} \\
\hline & \multicolumn{8}{|c|}{ Relative humidity (\%) } \\
\hline & 70 & 80 & 70 & 80 & 50 & 60 & 50 & 60 \\
\hline-1 & 8.9 & 10.8 & 21.6 & 24.6 & 84.2 & 94.3 & 110.0 & 124.8 \\
\hline-4 & 15.3 & 16.8 & 28.0 & 31.0 & 91.0 & 101.0 & 117.0 & 132.0 \\
\hline-7 & 20.9 & 22.7 & 34.0 & 36.9 & 97.6 & 108.1 & 124.1 & 139.0 \\
\hline-9 & 26.5 & 28.0 & 39.5 & 42.5 & 104.3 & 114.4 & 130.8 & 149.1 \\
\hline-12 & 31.7 & 33.2 & 44.3 & 47.3 & 109.2 & 119.3 & 135.7 & 150.6 \\
\hline-15 & 36.5 & 38.4 & 50.0 & 53.0 & 116.3 & 126.7 & 143.1 & 159.1 \\
\hline-18 & 41.7 & 43.6 & 55.2 & 58.1 & 122.2 & 132.7 & 149.4 & 165.1 \\
\hline-21 & 45.8 & 47.7 & 59.3 & 62.2 & 127.1 & 137.5 & 154.7 & 170.3 \\
\hline-23 & 50.3 & 52.5 & 64.5 & 67.5 & 132.7 & 143.5 & 160.6 & 176.6 \\
\hline-26 & 56.0 & 57.0 & 68.9 & 71.6 & 136.8 & 147.6 & 164.7 & 181.1 \\
\hline-29 & 60.7 & 62.6 & 74.9 & 77.9 & 144.6 & 155.8 & 173.7 & 190.1 \\
\hline-32 & 66.0 & 67.1 & 79.0 & 82.4 & 149.1 & 160.2 & 178.1 & 194.2 \\
\hline-34 & 70.8 & 72.7 & 85.3 & 88.7 & 156.9 & 168.1 & 182.6 & 202.7 \\
\hline
\end{tabular}

\section{II.3.5 Miscellaneous Heat Load, $\mathrm{H}_{\mathrm{S}}$}

All sources of heat not covered by heat leakage, product cooling, and respiration load are usually listed as miscellaneous heat loads. Some of the more common miscellaneous heat loads are: lights, electric motors, people and defrosting heat sources. Miscellaneous heat load includes any other source of heat that may be obtained or introduced into the refrigerating space. It is represented as:

$$
\mathrm{H}_{\mathrm{S}}=\text { Motor load }+ \text { Lamp load }
$$

Mathematically:

$H_{S}=\left(n_{m} x P_{m} x t_{m} x h_{m}\right)+\left(n_{L} x P_{L} x t_{L} x C_{L}\right)$

where: $\mathrm{n}_{\mathrm{m}}=$ Number of motors in each cabin $=1$, $\mathrm{P}_{\mathrm{m}}=$ Power rating of electric motor per cabin = $0.03729 \mathrm{KW}$ (Table 3 ), $\mathrm{t}_{\mathrm{m}}=$ Period of time for motor fan to run $=24 \mathrm{hrs}, \mathrm{h}_{\mathrm{m}}=$ Heat released by operating electric motor (for $0.03729 \mathrm{KW}$ ) $=5236 \mathrm{KJ} / \mathrm{KWhr}$
(Table 3), $\mathrm{n}_{\mathrm{L}}=$ Number of lamps per cabin $=1, \mathrm{P}_{\mathrm{L}}=$ Lamp power rating $=40 \mathrm{Watt}, \mathrm{t}_{\mathrm{L}}=$ Period of time for operating lamp per day $=8$ hours, and $\mathrm{C}_{\mathrm{L}}=$ Energy per power rating $=3.6082 \mathrm{KJ} / \mathrm{Watt}$, respectively.

II.3.6 Occupancy Heat Load, $\mathrm{H}_{\mathrm{o}}$

This is the heat load released by individuals working inside the cold room. It is represented as:

$$
H_{O}=n_{P} x t_{P} x H_{e}
$$

where: $n_{P}=$ Number of persons working in each cabin per day $=2, t_{P}=$ Number of working hours per day $=8$ hours, and $\mathrm{H}_{\mathrm{e}}=$ Heat equivalent per hour (Table 4) which depends on each cabin cooler temperature in ${ }^{\circ} \mathrm{C}$. Hence:

$$
\text { Occupancy heat load, } \mathrm{H}_{\mathrm{o}}=16 H_{e}\left(\frac{K J}{24 h r}\right)
$$

II.3.7 Cabinet Areas, $A_{n} /$ Area of Insulation, $A_{i}$ 
The cabinet areas $\left(A_{n}\right)$ otherwise known as the area of insulation $\left(A_{i}\right)$ were calculated by considering the six sided cabin areas as follows:

$A_{n}=($ Ceiling and floor $)+($ two opposite ends $)+($ two opposite sides)

Mathematically, $A_{n}=(2 \mathrm{WL})+(2 \mathrm{WH})+(2 \mathrm{LH})$

$$
\therefore A_{n}=A_{i}=2(\mathrm{WL}+\mathrm{WH}=\mathrm{LH})
$$

where: $\mathrm{L}, \mathrm{W}$ and $\mathrm{H}$ are respectively, length, width and height in meters of each cabin.

\section{II.3.8 Cabinet Volume, V}

This volume was based on the inside dimensions of the cabinet. Thus, the insulation thickness $\left(I_{t}\right)$ on both sides of each of the six faces were not included in the volume determination. Hence:

$$
V_{n}=\left(L-2 I_{t}\right) x\left(W-2 I_{t}\right) x\left(H-2 I_{t}\right)
$$

For the design purposes, the following assumptions were made: $I_{t}=0.127 \mathrm{~m}(5 \mathrm{in})$, and $\mathrm{H}=2.7 \mathrm{~m}$. Thus, the cabin volume becomes:

$$
\begin{aligned}
& V_{n}=[(L-2 \times 0.127)] x[(W-2 \times 0.127)] \\
& x[(2.7-2 \times 0.127)] \\
= & {[(L-0.254)(W-0.254)(2.7-0.254)] } \\
\therefore \quad & V_{n}=2.446[(L-0.254)(W-0.254)]
\end{aligned}
$$

II.4 Analysis of the Vapour Compression Cycle Considering the P-h diagram as presented in Fig.4 similar to Fig.3, four basic flow processes that continue in a cycle employing R134a refrigerant as the working fluid, exist.

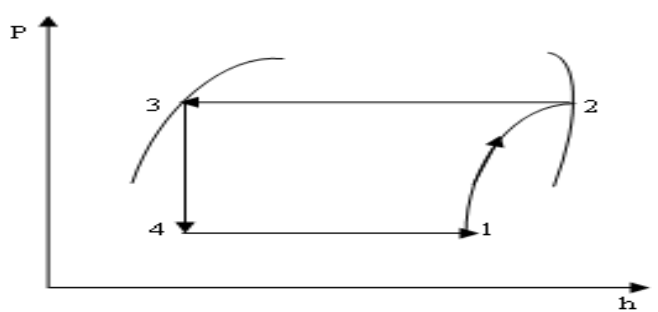

Fig.4: P-h Diagram involving the steady state energy flow equation

The vapour compression cycle is analyzed as follows:

$$
h_{1}+\frac{C_{1}^{2}}{2}+Q+W=h_{2}+\frac{C_{0}^{2}}{2}
$$

Neglecting the kinetic energy transfer by assuming that: $\frac{C_{1}^{2}}{2}=\frac{C_{0}{ }^{2}}{2}=0$, gives:

$$
h_{1}+Q+W=h_{2}
$$

where: $\mathrm{h}_{1}=$ Enthalpy at inlet to the process, $\mathrm{h}_{2}=$ Enthalpy at outlet, $\mathrm{W}=$ Work done during the process, and $\mathrm{Q}=$ Heat transferred, respectively.

Table 3: Heat Released by Operating Electric Motors (KJ/KWhr)

\begin{tabular}{|c|c|c|c|c|}
\hline S/N & $\begin{array}{c}\text { Motor power rating } \\
\text { KW }\end{array}$ & $\begin{array}{c}\text { Connected load in refrigerated } \\
\text { space }\end{array}$ & Motor losses outside R.Sp & $\begin{array}{c}\text { Connected Load Outside } \\
\text { R.Sp }^{\mathbf{3}}\end{array}$ \\
\hline 1 & 0.0932 to 0.3729 & 6014 & 3601 & 2406 \\
\hline 2 & 0.03729 to 2.2371 & 5236 & 3601 & 1627 \\
\hline 3 & 2.2371 to 14.9140 & 4174 & 3601 & 566 \\
\hline
\end{tabular}

Table 4: Heat Released by a Person in the Cooled Space (Refrigerated Space)

\begin{tabular}{|c|c|c|}
\hline \multirow{2}{*}{$\mathbf{S} / \mathbf{N}$} & \multicolumn{2}{|c|}{ Heat released per occupant } \\
\cline { 2 - 3 } & Cooler temperature $\left({ }^{\mathbf{0}} \mathbf{C}\right)$ & Heat released/person (KJ/hr) \\
\hline 1 & 10 & 760 \\
\hline 2 & 4 & 886 \\
\hline 3 & -1 & 1002 \\
\hline 4 & -7 & 1108 \\
\hline 5 & -12 & 1266 \\
\hline 6 & -18 & 1372 \\
\hline 7 & -23 & 1477 \\
\hline
\end{tabular}

II.4.1 Work Done by Compressor, $\mathrm{W}_{\mathrm{C}}$

The work done to compress the refrigerant vapour according to Raynor [1] is obtained by applying (10) to the compression process: 1-2. Hence:

$$
\mathrm{h}_{1}+\mathrm{Q}+\mathrm{W}=\mathrm{h}_{2}
$$

But: $\mathrm{Q}=0$ since heat is usually neglected nor extracted nor added during compression process. 
Thus: $\mathrm{h}_{1}+\mathrm{W}=\mathrm{h}_{2}$

$$
\therefore \quad W_{C}=h_{2}-h_{1}
$$

This is the work done per $\mathrm{kg}$ of the refrigerant.

\section{II.4.2 Compressor Capacity, P}

This is also the power input (electrical) into the hermetic motor compressor. Power input refers to the rate at which the refrigerant vapour is compressed. It is the product of the mass flow rate and the work done. Thus:

$$
P=M\left(h_{2}-h_{1}\right)
$$

where: $M=$ The mass flow rate of the refrigerant .

\section{II.4.3 Mass Flow rate of refrigerant, $\mathrm{M}$}

This is the quantity of refrigerant (in $\mathrm{kg}$ ) that must flow through a system per unit time to produce a ton of refrigerant. This is defined and stated as:

$$
\begin{gathered}
M=\frac{\text { Refrigeration capacity of system }}{\text { Refrigeration effect of refrigerant }} \\
\text { Mathematically, } \quad M=\frac{C_{R}}{h_{1}-h_{4}}
\end{gathered}
$$

where: $C_{R}=$ The refrigeration capacity (or total heat load of the cold room, $\mathrm{H}_{\mathrm{T}}$ ).

\section{II.4.4 Condenser capacity, $\mathrm{C}_{\mathrm{C}}$}

This is the heat rejected by the refrigerant in unit time in the condenser. Invoking (10): $h_{2}+Q_{23}+W=h_{3}$ But: $\mathrm{W}=0$ (as no work is done in the condenser). Hence: $\mathrm{h}_{2}+\mathrm{Q}_{23}=\mathrm{h}_{3}$

$$
\therefore \quad \mathrm{Q}_{23}=\mathrm{h}_{3}-\mathrm{h}_{2}
$$

It should be noted here that $h_{2}>h_{3}$. Thus, $Q_{23}$ will be negative although its magnitude is $h_{2}-h_{3}$. Therefore, the condenser capacity, $\mathrm{C}_{\mathrm{C}}$ is obtained as:

$$
C_{C}=M Q_{23}=M\left(h_{2}-h_{3}\right)
$$

\section{II.4.5 Refrigeration Effect, $\mathrm{Q}_{41}$}

This is the quantity of heat that a unit mass of refrigerant absorbs from the refrigerated space. This takes place at the evaporator. The refrigeration effect, $\mathrm{Q}_{41}$, is obtained from the refrigeration process: 4-1 by invoking the energy equation, (10). Hence:

$\mathrm{h}_{4}+\mathrm{Q}_{41}+\mathrm{W}=\mathrm{h}_{1}$. But: $\mathrm{W}=0$. Thus: $\mathrm{h}_{4}+\mathrm{Q}_{41}=\mathrm{h}_{1}$

$$
\therefore \quad Q_{41}=h_{1}-h_{4}
$$

\section{II.4.6 Evaporator Capacity, $\mathrm{C}_{\mathrm{E}}$}

This is also known as the refrigerator system capacity which is defined as the rate at which heat is removed from the refrigerated space. This is also the product of mass flow rate $(\mathrm{M})$ and the refrigerating effect, $\mathrm{Q}_{41}$. Hence: $\quad \mathrm{C}_{\mathrm{E}}=\mathrm{M} \mathrm{Q}_{41}$

$$
\therefore \quad C_{E}=M\left(h_{1}-h_{4}\right)
$$

\section{II.4.7 Volume Flow Rate, V}

This is the amount of saturated vapour $\left(\mathrm{m}^{3}\right)$ produced when $1 \mathrm{~kg}$ of refrigerant vaporizes. This depends on the refrigerant $\left(\mathrm{R} 134_{\mathrm{a}}\right)$ used and its vaporizing temperature. When the vaporizing temperature of R134 is known, the volume of the vapour produced per unit mass (specific volume) is usually determined from the saturated tables. Thus:

$$
\mathrm{V}=\mathrm{MV}
$$

where: $\mathrm{V}=$ Specific volume of vapour.

\section{II.4.8 Throttling Process}

This is the process 3-4 in the P-h diagram of Fig.4. It is an increasable adiabatic (isentropic) process at constant enthalpy in which no work is done and no heat transfer takes place. Thus, invoking the energy equation, (10): $\mathrm{h}_{3}+\mathrm{Q}+\mathrm{W}=\mathrm{h}_{4}$. But: $\mathrm{Q}=\mathrm{W}=0$

$$
\therefore \quad \mathrm{h}_{3}=\mathrm{h}_{4}
$$

\section{II.4.9 Coefficient of Performance, COP}

This is the parameter used to measure the performance of the refrigeration system as a ratio of the output to the input work. Hence:

$$
\begin{aligned}
& \text { COP }=\frac{\text { Refrigeration effect }}{\text { Work done }}=\frac{Q_{41}}{W_{12}} \\
& \text { Mathematically, } C O P=\frac{h_{1}-h_{4}}{h_{2}-h_{1}}
\end{aligned}
$$

\section{II.5 Heat Transfer Calculations}

According to Rajput [14], the result of the heat transfer rate through a solid by conduction is given as:

$$
Q=U A T_{D}
$$


where: $\mathrm{Q}=$ Rate of heat flow $(\mathrm{KW})$, and $\mathrm{A}=$ Surface area of the pipe component $\left(\mathrm{m}^{2}\right)$, and

$$
T_{D}=\left(t_{r}-t_{a}\right)
$$

wherefore: $t_{r}=$ Refrigerant temperature, $t_{a}=$ Maximum atmospheric temperature, and $\mathrm{U}=$ Overall heat transfer coefficient $\left(\frac{K W}{m^{2} K}\right)$ given as:

$$
U=\frac{1}{\frac{r_{2}}{r_{1} h}+\frac{r_{2}}{K_{1}} \ln \frac{r_{2}}{r_{1}}}
$$

where: $r_{2}=$ Tube outer radius, $r_{1}=$ Tube inner radius, $\mathrm{h}=$ Convective heat transfer coefficient, and $\mathrm{k}_{1}=$ Thermal conductivity of material, respectively.

\section{II.5.1 Other important relations}

Other important parameters and relations required for proper determination of the heating load of the cold storage rooms are given below as:

$$
\text { (a) i. } \quad N u=\frac{h d_{1}}{K}
$$

or: $N u=0.023 R_{e}^{0.8} P_{r}^{n}$ (for turbulent flow)

$$
\text { ii. } \quad R_{e}=\frac{V d_{1} \rho}{\mu}
$$

and

$$
\text { iii. } \quad P_{r}=\frac{\mu C_{P}}{K}
$$

where: $\mathrm{Nu}=$ The generally required dimensionless quantity used in practical application that includes convective heat transfer coefficient and known as the Nusselt number, $d_{1}=$ Inside diameter of the tube, $K=$ Thermal conductivity of fluid, $\mathrm{R}_{\mathrm{e}}=$ Reynold's number, $\mathrm{P}_{\mathrm{r}}=$ Prandtl number, $\mathrm{n}=$ Constant $=0.3$ (for cooling fluids) and 0.4 (for heating fluids), respectively; $\mathrm{v}=$ Velocity of the fluid flow $(\mathrm{m} / \mathrm{s}), \rho=$ Fluid density $\left(\mathrm{kg} / \mathrm{m}^{3}\right), \mu=$ Absolute viscosity $(\mathrm{kg} / \mathrm{ms})$, and $\mathrm{C}_{\mathrm{p}}=$ Specific heat capacity at constant pressure $(\mathrm{KJ} / \mathrm{KgK})$, respectively.

iv. Surface Area of the Pipe Component, $\mathrm{m}^{2}$

This is given as: $A=\pi d_{1} L$

where: $\pi=3.142$ and $\mathrm{L}=$ Length of the tube.

v. The Condenser Capacity, $\mathrm{C}_{\mathrm{C}}$

This is given as: $C_{C}=F T_{D}$ vi. The Heat Rejection Factor, HRF

This is given as: $H R F=\frac{C_{C}}{C_{R}}$

where: $\mathrm{HRF}=$ Heat rejection factor, $\mathrm{Cc}=$ Condenser capacity, and $\mathrm{C}_{\mathrm{R}}=$ Refrigeration capacity (or total heat load of the storage room, $\mathrm{H}_{\mathrm{T}}$ ).

vii. The Volume of the Receiver, $V_{R}$

This is given by: $V_{R}=V_{C}+V_{E}$

Thus: $\quad V_{R}=\frac{\pi d_{C}^{2} L_{C}}{4}+\frac{\pi d_{E}^{2} L_{E}}{4}$

$$
\therefore \quad V_{R}=\frac{\pi d_{R}^{2} L_{R}}{4}
$$

where: $\mathrm{V}=$ Volume, $\mathrm{d}=$ Diameter, and $\mathrm{L}=$ Length with the subscripts representing respectively, $\mathrm{R}=$ Receiver, $\mathrm{C}=$ Condenser, and $\mathrm{E}=$ Evaporator.

viii. Insulation Area, $A_{n}$

The area of insulation was obtained from (20).

Hence: $\quad A_{n}=\frac{Q}{U T_{D}}$

Here, Q (KJ) indicates the heat that flows from the surrounding (ambient) into the cold room cabins in a second.

\section{(b) Refrigerant Piping}

i. Liquid Line: This is the pipe line connecting the liquid receiver to the expansion valve. It is not as critical as the suction and the discharge lines. For $\mathrm{R} 134_{\mathrm{a}}$, the following specifications were recommended: The pressure drop was specified as between 0.0069 to $0.0115 \mathrm{bar} / \mathrm{m}$ for $0.82 \mathrm{TR}$ capacity. This approximates to 1TR. In horse power, its equivalence is $4 \mathrm{Hp}$ capacity of the heat load for the cold room. It has also a liquid line size of $0.5 \mathrm{~cm}$ OD (Outside diameter) which is insulated to prevent outside heat from flowing into the liquid.

ii. Suction Line: This is the line connecting the compressor inlet to the evaporator outlet. For average condition and for R134 a, the pressure drop range is from 0.069 to $0.103 \mathrm{bar} / \mathrm{m}$. Conversely, for $0.82 \mathrm{TR}$ capacity or the $4 \mathrm{Hp}$ capacity heat load, the suction size was selected as $1.5 \mathrm{~cm}$ OD.

where: $\mathrm{F}=$ Condenser performance. 
IOSR Journal of Engineering

May. 2012, Vol. 2(5) pp: 1234-1250

iii. Discharge Line: This is the line connecting the compressor outlet and the condenser inlet. The pressure drop was selected as $0.0023 \mathrm{bar} / \mathrm{m}$ for $0.82 \mathrm{TR}$ capacity or the $4 \mathrm{Hp}$ capacity heat load with the discharge line size of $0.85 \mathrm{~cm}$.

\section{DESIGN CALCULATIONS}

III.1 Parameters' Designations and Specifications

III.1.1 Psychrometric Properties of R134a

The following values and parameters specified below were selected from the psychrometric chart of the refrigerant, R134a and from the Properties tables according to Eugene [15] and Robert [16], respectively. Thus:

The Operating temperature range $=-15^{0} \mathrm{C}$ to $35^{\circ} \mathrm{C}$ (258 to 308K); Suction pressure, $\mathrm{P}_{1}=\mathrm{P}_{4}=343 \mathrm{KP}_{\mathrm{a}}$; Heat pressure, $\mathrm{P}_{2}=\mathrm{P}_{3}=958 \mathrm{KP}_{\mathrm{a}}$; Ratio of heat to suction pressure $=2.79$; Theoretical power $=0.68 \mathrm{HP}$; Discharge temperature $=14^{0} \mathrm{C}(287 \mathrm{~K})$; Boiling point $=-26^{\circ} \mathrm{C}(247 \mathrm{~K}) ;$ Critical temperature $=101^{\circ} \mathrm{C}$ $(374 \mathrm{~K})$; Critical pressure $=4052 \mathrm{KP}_{\mathrm{a}}$; Liquid velocity $=0.505 \mathrm{~m} / \mathrm{s} ;$ Suction line velocity $=10.15 \mathrm{~m} / \mathrm{s}$;
Discharge line velocity $=15.24 \mathrm{~m} / \mathrm{s} ; \mathrm{h}_{1}=233 \mathrm{KJ} / \mathrm{kg}$; $\mathrm{h}_{2}=256 \mathrm{KJ} / \mathrm{kg} ; \mathrm{h}_{3}=\mathrm{h}_{4}=93 \mathrm{KJ} / \mathrm{kg} ; \mathrm{V}_{1}=0.0624 \mathrm{~m}^{3} / \mathrm{kg}$; $\mathrm{V}_{2}=0.0262 \mathrm{~m}^{3} / \mathrm{kg} ; \quad \mathrm{V}_{3}=0.0037 \mathrm{~m}^{3} / \mathrm{kg} ; \quad \mathrm{V}_{4}=$ $0.0094 \mathrm{~m}^{3} / \mathrm{kg} ; \mathrm{T}_{1}=\mathrm{T}_{4}=10^{0} \mathrm{C}(283 \mathrm{~K}) ;$ and $\mathrm{T}_{2}=\mathrm{T}_{3}=$ $30^{\circ} \mathrm{C}(303 \mathrm{~K})$, respectively.

III.1.2 Thermal Properties of the Refrigerant

The thermal properties of the refrigerant, R134a at $-15^{\circ} \mathrm{C}$ according to Robert [16] are specified as:

Thermal conductivity, $\mathrm{K}=9.048 \times 10^{-3} \mathrm{~W} / \mathrm{mK}$; Dynamic viscosity, $\mu=1.128 \times 10^{-5} \mathrm{Kg} / \mathrm{ms}$; Kinematic viscosity, $\mathrm{K}=0.85 \times 10^{-6} \mathrm{~m}^{2} / \mathrm{s}$; Density of $\mathrm{R} 134_{\mathrm{a}}$ vapour $=13.271 \mathrm{Kg} / \mathrm{m}^{3}$; and Prandtl number, $\mathrm{P}_{\mathrm{r}}$ $=0.68$, respectively.

Conversely, its thermal properties at $38^{\circ} \mathrm{C}$ according to the same source are also: Thermal conductively, $\mathrm{K}$ $=0.0824 \mathrm{~W} / \mathrm{mK} ;$ Dynamic viscosity, $\mu=$ $0.00202 \mathrm{Kg} / \mathrm{ms}$; Kinematic viscosity, $\mathrm{K}=2 \times 10^{-7}$ $\mathrm{m}^{2} / \mathrm{s}$; Density, $\rho=1010 \mathrm{Kg} / \mathrm{m}^{3}$; Velocity of liquid, $\mathrm{V}$ $=0.508 \mathrm{~m} / \mathrm{s} ;$ and Prandtl number, $\mathrm{P}_{\mathrm{r}}=3.25$, respectively.

Table 5: Heat Gain Factors for Walls, Floor and Ceiling [KJ/ $\left.\left(\mathrm{m}^{2}\right)(24 \mathrm{hr})\right]$

\begin{tabular}{|c|c|c|c|c|c|c|c|c|c|c|c|c|c|c|c|c|c|c|}
\hline Insulation & \multicolumn{18}{|c|}{ Temperature difference(ambient temperature minus storage temperature), ${ }^{\mathbf{0}} \mathrm{c}$} \\
\hline $\begin{array}{l}\text { Cork or } \\
\text { equivalent } \\
\text { (in) }\end{array}$ & 0.56 & 22.2 & 25 & 27.8 & 30.6 & 33.3 & 36.1 & 38.9 & 41.7 & 44.4 & 47.2 & 50 & 52.8 & 55.6 & 58.3 & 61.1 & 63.9 & 66.7 \\
\hline 0.0762 & 27 & 1090 & 1226 & 1363 & 1499 & 1635 & 1772 & 1908 & 2044 & $\begin{array}{l}44.4 \\
2180\end{array}$ & 2317 & 2453 & 2589 & 2725 & 2862 & 2998 & 3134 & 3271 \\
\hline 0.1016 & 20 & 818 & 920 & 1022 & 1124 & 1226 & 1329 & 1431 & 1533 & 1635 & 1737 & 1840 & 1942 & 2044 & 2146 & 2248 & 2351 & 2453 \\
\hline 0.127 & 16 & 659 & 738 & 818 & 897 & 988 & 1067 & 1147 & 1226 & 1306 & 1385 & 1476 & 1556 & 1635 & 1715 & 1806 & 1885 & 1965 \\
\hline 0.1524 & 13.6 & 545 & 613 & 681 & 749 & 818 & 886 & 954 & 1022 & 1090 & 1158 & 1226 & 1295 & 1363 & 1431 & 1499 & 1567 & 1635 \\
\hline 0.1778 & 11.7 & 466 & 522 & 591 & 647 & 704 & 761 & 818 & 8744 & 931 & 999 & 1056 & 1113 & 1170 & 1226 & 1283 & 1340 & 1408 \\
\hline 0.2032 & 10 & 409 & 466 & 511 & 568 & 613 & 670 & 715 & 772 & 818 & 874 & 920 & 977 & 1022 & 1079 & 1124 & 1181 & 1226 \\
\hline 0.2286 & 9 & 363 & 409 & 454 & 500 & 545 & 591 & 636 & 681 & 727 & 772 & 818 & 863 & 908 & 954 & 999 & 1045 & 1090 \\
\hline 0.254 & 8 & 329 & 363 & 409 & 454 & 488 & 534 & 568 & 613 & 659 & 693 & 738 & 772 & 818 & 863 & 897 & 943 & 977 \\
\hline 0.2794 & 7 & 295 & 340 & 375 & 409 & 454 & 488 & 522 & 568 & 602 & 636 & 681 & 715 & 749 & 784 & 829 & 863 & 897 \\
\hline 0.3048 & 6.8 & 273 & 307 & 340 & 375 & 409 & 443 & 477 & 511 & 545 & 579 & 613 & 647 & 681 & 715 & 749 & 784 & 818 \\
\hline 0.3302 & & & & & & & & & & & & & & & & & & \\
\hline $\begin{array}{c}0.3556 \\
\text { Singleglass }\end{array}$ & $\begin{array}{c}5.8 \\
306.6\end{array}$ & $\begin{array}{l}227 \\
12.264\end{array}$ & $\begin{array}{c}261 \\
13854\end{array}$ & $\begin{array}{r}295 \\
13531\end{array}$ & $\begin{array}{c}318 \\
16920\end{array}$ & $\begin{array}{c}352 \\
18397\end{array}$ & $\begin{array}{c}375 \\
1998\end{array}$ & ${ }_{209}^{409}$ & ${ }_{2303}^{432}$ & $\begin{array}{l}466 \\
24529\end{array}$ & $\begin{array}{c}488 \\
2605\end{array}$ & $\begin{array}{r}522 \\
27709\end{array}$ & $\begin{array}{c}556 \\
29071\end{array}$ & $\begin{array}{r}579 \\
3066\end{array}$ & ${ }_{32251}^{613}$ & $\begin{array}{l}636 \\
33727\end{array}$ & $\begin{array}{l}670 \\
3520\end{array}$ & $\begin{array}{c}693 \\
3673\end{array}$ \\
\hline Doubleglass & 124.9 & 4997 & 5678 & 6246 & $\begin{array}{l}10927 \\
6927\end{array}$ & 7495 & 8120 & 8744 & 9369 & 9993 & 10629 & 11242 & $\begin{array}{l}2,1924 \\
1191\end{array}$ & $\begin{array}{l}5001 \\
12492\end{array}$ & $\begin{array}{l}0251 \\
13173\end{array}$ & $\begin{array}{l}33727 \\
13741\end{array}$ & $\begin{aligned} 5020 \\
14422\end{aligned}$ & $\begin{array}{l}30 / 90 \\
14990\end{array}$ \\
\hline $\begin{array}{l}\text { Doubregias } \\
\text { Triple glass }\end{array}$ & 79.5 & 3180 & 3634 & 3975 & 4429 & 4770 & 5156 & 5564 & 5962 & 6359 & 6757 & 7154 & 7552 & $\begin{array}{l}12428 \\
7949\end{array}$ & 8403 & $\begin{array}{l}17741 \\
8744\end{array}$ & $\begin{array}{l}14198 \\
9192\end{array}$ & $\begin{array}{l}149700 \\
9539\end{array}$ \\
\hline
\end{tabular}

III.2 Heat Load Calculations

III.2.1 Miscellaneous heat load, $\mathrm{H}_{\mathrm{S}}$

From (4b): $H_{S}=\left(n_{m} x P_{m} x t_{m} x h_{m}\right)+$

$\left(n_{L} x P_{L} x t_{L} x C_{L}\right)$ becomes:

$(1 \times 0.03729 \times 24 \times 5236)+(1 \times 40 \times 8 \times 3.6082)$

$=4686.01+1154.62=5840.63 \mathrm{KJ} / 24 \mathrm{hrs}$
III.2.2 Cabinet Areas, $A_{n}$ or $A_{i}$

Recall: $A_{n}=A_{i}=2(\mathrm{WL}+\mathrm{WH}=\mathrm{LH})$

The food products that are assumed to occupy the cold room store are mainly meat, fish and dairy products. Also, recall: the length of the room $=4.6 \mathrm{~m}$, the width of the room $=3 \mathrm{~m}$, the height of the room $=2.7 \mathrm{~m}$, and the thickness of the walls $=0.127 \mathrm{~m}(5 \mathrm{in})$, respectively. Thus: Cabinet 
area/Area of insulation, $\left(\mathrm{A}_{\mathrm{n}}\right)=2[(3 \times 4.6)+(3 \times 2.7)+(4.6$ $x$ 2.7)]

$$
\begin{aligned}
& =2(13.8+8.1+12.42) \\
\therefore \quad & A_{n}=2(34.32)=68.64 m^{2}
\end{aligned}
$$

\section{III.2.3 Cabinet volume, V}

$$
\text { Recall: } V_{n}=\left(L-2 I_{t}\right) x\left(W-2 I_{t}\right) x\left(H-2 I_{t}\right)
$$

Hence: Cabinet volume, $\mathrm{V}$ becomes:

$$
\begin{aligned}
\mathrm{V} & =[\{\mathrm{L}-(2 \times 0.127)\}] \times[\{\mathrm{W}-(2 \times 0.127)\}] \times \\
& {[\{\mathrm{H}-(2 \times 0.127)\}] } \\
= & {[(\mathrm{L}-0.254) \times(\mathrm{W}-0.254) \times(\mathrm{H}-0.254)] } \\
= & (4.6-0.254) \times(3-0.254) \times(2.7-0.254) \\
\therefore & V_{n}=\mathrm{V}=4.346 \times 2.746 \times 2.446=29.19 \mathrm{~m}^{3}
\end{aligned}
$$

III.2.4 Heat leakage load, $\mathrm{H}_{\mathrm{L}}$

Recall: Heat leakage load, $\mathrm{H}_{\mathrm{L}}=\mathrm{H}_{\mathrm{g}} \times \mathrm{A}_{\mathrm{n}}$

But: Temperature difference

$=$ Ambient temperature - Storage temperature

where: Ambient temperature $=36^{\circ} \mathrm{C}$ [10]. Thus:

$$
T_{d}=t_{a}-t_{S}
$$

$T_{d}=$ Temperature difference, $t_{a}=$ Ambient temperature, and $\mathrm{t}_{\mathrm{S}}=$ Storage temperature $=-5^{\circ} \mathrm{C}$ (Assumed). Hence: $\mathrm{T}_{\mathrm{d}}=$ $36-(-5)=41^{\circ} \mathrm{C}$

But, from Table 5, for $41^{\circ} \mathrm{C}$ temperature difference and $0.127 \mathrm{~m}$ (5in) insulation thickness, the heat gain factor or the heat of insulation, $\mathrm{H}_{\mathrm{g}}$ is interpolated as:

$$
\begin{gathered}
\frac{38.9-41}{1147-x}=\frac{41-41.7}{x-1226}=\frac{-2.1}{1147-x}=\frac{-0.7}{x-1226} \\
=-2.1(x-1226)=-0.7(1147-x) \\
=-2.1 x+2574.6=-802.9+0.7 x \\
=-2.8 x=-3377.5 \\
\therefore x=\frac{3377.5}{2.8}=1206.25 \mathrm{KJ} /\left(\mathrm{m}^{2}\right)(24 \mathrm{hr})=\mathrm{H}_{\mathrm{g}}
\end{gathered}
$$

Thus: Heat leakage load, $\mathrm{H}_{\mathrm{L}}=1206.25 \times 68.64$

$$
=82797 \mathrm{KJ} / 24 \mathrm{hr}
$$

III.2.5 Air change heat load, $\mathrm{H}_{\mathrm{C}}$

Recall: $H_{C}=V \times A_{C} \times H_{m}$

But: Cabinet volume, $\mathrm{V}=29.19 \mathrm{~m}^{2}$ (as already calculated). Air changes per $24 \mathrm{hrs}, \mathrm{A}_{\mathrm{C}}=17.28$ (interpolated value from Table 1), and heat per $\mathrm{m}^{3}, \mathrm{H}_{\mathrm{m}}=119.3 \mathrm{KJ} / \mathrm{m}^{3}$ (interpolated value from Table 2). Thus:
Air change heat load, $\mathrm{H}_{\mathrm{C}}=29.19 \times 17.28 \times 119.3$

$$
\therefore \quad \mathrm{H}_{\mathrm{C}}=60175.30 \mathrm{KJ} / 24 \mathrm{hr}
$$

III.2.6 Product heat load, $\mathrm{H}_{\mathrm{P}}=\mathrm{W}_{\mathrm{t}} \mathrm{CT}$

Recall (3). But: $\mathrm{W}_{\mathrm{t}}=2000 \mathrm{Kg}$ (Assumed value of the total food items' weight to be stored in the cabinets), $\mathrm{C}=$ $1 \mathrm{KJ} / \mathrm{KgK}$, and:

$T=T_{\text {food products }}-T_{\text {cooler for food products }}$ (i.e. assumed storage temperature) $=37-(-5)=42^{\circ} \mathrm{C}$

$$
\therefore \text { Product heat load, } \mathrm{H}_{\mathrm{P}}=2000 \mathrm{x} 1 \mathrm{x} 42
$$

$$
=84000 \mathrm{KJ} / 24 \mathrm{hr}
$$

III.2.7 Occupancy heat load, $\mathrm{H}_{\mathrm{o}}$

From (5b),

Occupancy heat load, $\mathrm{H}_{\mathrm{o}}=16 \mathrm{H}_{\mathrm{e}} \quad(\mathrm{KJ} / 24 \mathrm{hr})$

But since: $\mathrm{H}_{\mathrm{e}}=$ Heat equivalent per hour, from Table 5 by interpolation, it becomes:

$$
\begin{gathered}
\frac{-1-(-5)}{1002-x}=\frac{-5-(-7)}{x-1108}=\frac{4}{1002-x}=\frac{2}{x-1108} \\
=4(x-1108)=2(1002-x) \\
=4 x-4432=2004-2 x \\
=6 x=6436 \\
\therefore x=\frac{6436}{6}=1072.7 \mathrm{KJ} / 24 \mathrm{hr}=\mathrm{H}_{\mathrm{e}}
\end{gathered}
$$

Hence: Occupancy heat load, $\mathrm{H}_{\mathrm{o}}=16$ x 1072.7

$$
=17163.2 \mathrm{KJ} / 24 \mathrm{hr}
$$

III.2.8 Total heat load, $\mathrm{H}_{\mathrm{T}}$

This is given as:

$\mathrm{H}_{\mathrm{T}}=$ Heat leakage load $\left(\mathrm{H}_{\mathrm{L}}\right)+$ Air change heat load $\left(\mathrm{H}_{\mathrm{C}}\right)+$ Product heat load $\left(\mathrm{H}_{\mathrm{P}}\right)+$ Miscellaneous heat load $\left(\mathrm{H}_{\mathrm{S}}\right)+$ Occupancy heat load $\left(\mathrm{H}_{\mathrm{o}}\right)$. Hence:

$$
\begin{aligned}
\mathrm{H}_{\mathrm{T}}= & 82797+60175.30+84000+5840.63 \\
& +17163.2=249976.13 \mathrm{KJ} / 24 \mathrm{hr}
\end{aligned}
$$

For 1 hour, $\mathrm{H}_{\mathrm{T}}=\frac{249976.13}{24}=10415.67 \mathrm{KJ} / \mathrm{hr}$

Also: $1 \mathrm{TR}=12660 \mathrm{KJ} / \mathrm{hr}[11]$. Thus: $10415.67 \mathrm{KJ} / \mathrm{hr}=0.82 \mathrm{TR}(\cong 1 \mathrm{TR})$

Also, in $\mathrm{KJ} / \mathrm{s}$, total heat load, $\mathrm{H}_{\mathrm{T}}=\frac{249976.13(K J)}{24 \times 3600(s)}$

$$
=\frac{249976.13}{86400}=2.893 \mathrm{KJ} / \mathrm{s}(2893 \mathrm{~J} / \mathrm{s} \text { or } 2893 \mathrm{Watts})
$$

Hence:

Total heat load, $\mathrm{H}_{\mathrm{T}}=2893$ Watts $(2.893 \mathrm{KW})$

$$
\text { or } 3.8796 \mathrm{Hp}(\cong 4 H p)
$$

\section{III.3 Compressor Design}


III.3.1 Work done by the compressor, $\mathrm{W}_{\mathrm{C}}$

Recall (11): $W_{C}=h_{2}-h_{1}$

But: $h_{1}=233 \mathrm{KJ} / \mathrm{Kg}$ and $h_{2}=256 \mathrm{KJ} / \mathrm{Kg}$ (section III.1.1).

Thus: $\mathrm{W}_{\mathrm{C}}=256-233=23 \mathrm{KJ} / \mathrm{Kg}$

III.3.2 Mass flow rate of refrigerant, $\mathrm{M}$

According to [1], $M=\frac{C_{R}}{h_{1}-h_{4}} \quad$ [Recall: $\left.(12 \mathrm{~b})\right]$

Hence: $\quad \frac{2893(\mathrm{~J} / \mathrm{s})}{(233-93) \times 10^{3} \mathrm{~J} / \mathrm{Kg}}=\frac{2893}{140 \times 10^{3}}$

$$
=\frac{2893}{140000}=0.02 \mathrm{Kg} / \mathrm{s}
$$

III.3.3 Compressor capacity, $\mathrm{P}$

Recall (12): $\mathrm{P}=\mathrm{M}\left(\mathrm{h}_{2}-\mathrm{h}_{1}\right) \quad$ [1]

Hence: $\mathrm{P}=0.02(256-233) \times 10^{3}=0.02(23) \times 1000$

$$
\therefore \quad \mathrm{P}=460 \mathrm{~J} / \mathrm{s}=0.46 \mathrm{KW} \text { or } 0.61 \mathrm{Hp}(\cong 1 \mathrm{Hp})
$$

III.3.4 Refrigeration effect, $\mathrm{Q}_{41}$

Recall (15): $\mathrm{Q}_{41}=\mathrm{h}_{1}-\mathrm{h}_{4} \quad$ [1]

Thus: $\mathrm{Q}_{41}=(233-93) \times 10^{3}=140 \times 1000$

$$
\therefore \mathrm{Q}_{41}=140,000 \mathrm{~J} / \mathrm{Kg}=140 \mathrm{KJ} / \mathrm{kg}
$$

III.3.5 Volume Flow Rate, V

Recall (17): $\mathrm{V}=\mathrm{M} \times \mathrm{V}$ [1]

Thus: $\mathrm{V}=0.02\left(\mathrm{~V}_{4}-\mathrm{V}_{3}\right)$

But since R134a vaporizes at the expansion or throttle state (i.e. process 3 to 4 ), the specific volumes of the vapour at those states were obtained from the saturated tables as: $\mathrm{V}_{3}=$ $0.0037 \mathrm{~m}^{3} / \mathrm{Kg}$ and $\mathrm{V}_{4}=0.0094 \mathrm{~m}^{3} / \mathrm{Kg}$, respectively (see section III.1.1).

Thus: $\mathrm{V}=0.02(0.0094-0.0037)=0.02(0.0057)$

$$
\therefore \quad \mathrm{V}=0.000114 \mathrm{~m}^{3} / \mathrm{s}
$$

III.3.6 Coefficient of Performance, COP

Recall (19b): $\quad C O P=\frac{Q_{41}}{W_{12}}=\frac{h_{1}-h_{4}}{h_{2}-h_{1}}=\frac{Q_{41}}{W_{C}} \quad$ [1]

$$
\therefore \quad C O P=\frac{140 \mathrm{KJ} / \mathrm{Kg}}{23 \mathrm{KJ} / \mathrm{Kg}}=6.09
$$

III.3.7 Rated power, $\mathrm{P}_{\text {rated }}$

According to Raynor [1], rated power,

$$
P_{\text {rated }}=\frac{\text { Compressor capacity }}{(C O P)_{\text {actual }}}=\frac{P}{(C O P)_{\text {actual }}}
$$

where: $(C O P)_{\text {actual }}=\left(\frac{1}{3}\right) x(C O P)$

Hence: $(C O P)_{\text {actual }}=0.3333 \times 6.09=2.03$

Thus: $P_{\text {rated }}=\frac{460 \mathrm{~J} / \mathrm{s}}{2.03}=226.6 \mathrm{~W}$

$$
\therefore P_{\text {rated }}=0.2266 \mathrm{KW} \text { or } 0.3039 \mathrm{Hp}
$$

\section{III.4 Condenser Design}

III.4.1 Condenser capacity, $\mathrm{C}_{\mathrm{C}}$

Recall (14): $\mathrm{C}_{\mathrm{C}}=\mathrm{M}\left(\mathrm{h}_{2}-\mathrm{h}_{3}\right)$

Thus: $\mathrm{C}_{\mathrm{C}}=0.02(256-93) \times 10^{3}=0.02(163) \times 1000$

$$
\therefore \mathrm{C}_{\mathrm{C}}=3260 \mathrm{~J} / \mathrm{s}(\mathrm{W})=3.26 \mathrm{KW} \text { or } 4.3717 \mathrm{Hp}
$$

Also, the rated condenser capacity, $C_{c \text { rated }}$

$$
=\frac{\text { Condenser capacity }, C_{C}}{(\text { COP })_{\text {actual }}}=\frac{3260 \mathrm{~J} / \mathrm{s}}{2.03}=1605.9 \mathrm{~W}(1.6059 \mathrm{KW} \text { or }
$$

$$
2.1535 \mathrm{Hp})
$$

III.4.2 Condenser tube diameter

For a condensing capacity of $3260 \mathrm{~J} / \mathrm{s}$, the following condenser configurational parameters were selected:

Internal diameter, $d_{C 1}=0.015 \mathrm{~m}$; tube thickness, $t_{C}=$ $0.005 \mathrm{~m}$; external diameter, $d_{C 2}=0.017 \mathrm{~m}$; and tube material $=$ copper.

III.4.3 Surface Area of Condenser, $\mathrm{A}_{\mathrm{c}}$ Recall (20): $Q=U A_{C} T_{D}=C_{C} \quad$ [14]

Subject to (31): $A_{C}=\frac{C_{C}}{U T_{D}}=A_{n}$

But: $\mathrm{Q}=C_{C}=3.26 \mathrm{KW}$ and $T_{D}=t_{r}-t_{a}$

$$
=44-36=8^{\circ} \mathrm{C}(281 \mathrm{~K})
$$

where: $t_{r}=$ Refrigerant temperature $=44^{\circ} \mathrm{C}$ and $t_{a}=$ Maximum atmospheric temperature $=36^{\circ} \mathrm{C}$.

Also, recall (22): $\quad U=\frac{1}{\frac{r_{2}}{r_{1} h}+\frac{r_{2}}{K_{1}} \ln \frac{r_{2}}{r_{1}}}$

where: $r_{1}=\frac{d_{C 1}}{2}=\frac{0.015}{2}=0.0075 \mathrm{~m} ; r_{2}=\frac{d_{C 2}}{2}=\frac{0.017}{2}$

$=0.0085 \mathrm{~m}$; and thermal conductivity of copper, $\mathrm{K}_{1}=386$

$\mathrm{W} / \mathrm{mK}$.

To obtain the convective heat transfer coefficient of the condenser, $\mathrm{h}$, the following fluid flow parameters were used:

i. The Reynold's number relationship (25) [14] with the thermal properties of $\mathrm{R} 134 \mathrm{a}$ at $38^{\circ} \mathrm{C}$ (section III.1.2). Thus:

$$
\begin{gathered}
R_{e}=\frac{V d_{1} \rho}{\mu}=\frac{0.508 \times 0.015 \times 1010}{0.00202} \\
=\frac{7.6962}{0.00202}=3810
\end{gathered}
$$

Hence, with $R_{e}=3810$, the flow is turbulent. 
ii. Invoking Diltus-Boelter equation (24) for turbulency, the Nusselt parameter therefore becomes:

$$
N u=0.023 R_{e}^{0.8} P_{r}^{n}
$$

But: $\mathrm{n}=0.3$ for cooling fluid (see section II.5.1) and Prandtl number, $P_{r}=3.25$ (see section III.1.2) [14]. Thus:

$$
\begin{aligned}
& \mathrm{Nu}=0.023(3810)^{0.8} \times(3.25)^{0.3} \\
& =0.023(732.39)(1.4242)=23.99 \cong 24
\end{aligned}
$$

iii. Also, from (23), $N u=\frac{h d_{C 1}}{K}$

where: $\mathrm{K}=0.0824 \mathrm{~W} / \mathrm{mK}$ for $\mathrm{R} 134 \mathrm{a}$ at $38^{\circ} \mathrm{C}$. Hence:

$$
\mathrm{h}=\frac{N u K}{d_{C 1}}=\frac{24 \times 0.0824}{0.015}=\frac{1.9776}{0.015}
$$

$\therefore$ The convective heat transfer coefficient of the condenser, $\mathrm{h}=131.84 \mathrm{~W} / \mathrm{m}^{2} \mathrm{~K}$. Thus:

The overall heat transfer coefficient of the condenser,

$$
\begin{gathered}
\mathrm{U}=\frac{1}{\left(\frac{0.0085}{0.0075 \times 131.84}\right)+\frac{0.0085}{386} \ln \left(\frac{0.0085}{0.0075}\right)} \\
=\frac{1}{\left(\frac{0.0085}{0.9888}\right)+\frac{0.0085}{386} \ln \left(\frac{0.0085}{0.0075}\right)} \\
=\frac{1}{(0.008596278)+0.00002202 \ln (1.133333333)} \\
\frac{1}{(0.008596278)+0.00002202(0.125163143)} \\
\frac{1}{0.008596278+0.000002756} \\
\therefore \quad U=\frac{1}{0.008599034}=116.29 \mathrm{~W} / \mathrm{m}^{2} \mathrm{~K}
\end{gathered}
$$

Hence: the surface area of the condenser,

$$
\mathrm{A}_{\mathrm{C}}=\frac{3260}{116.29 \times 281}=\frac{3260}{32677.49}=0.0998 \mathrm{~m}^{2}
$$

III.4.4 Length of the condenser tubes, $\mathrm{L}_{\mathrm{C}}$

Recall (27): $A_{C}=\pi d_{C 1} L_{C}$

Hence: $L_{C}=\frac{A_{C}}{\pi d_{C 1}}=\frac{3.504}{3.142 \times 0.015}=\frac{3.504}{0.04713}=74.35 \mathrm{~m}$

\section{III.4.5 Condenser performance, $\mathrm{F}$}

According to Andrew, et al [2], $C_{C}=F T_{D}$

Hence: $\quad \mathrm{F}=\frac{C_{C}}{T_{D}}=\frac{3260}{281}=11.60 \mathrm{KW} / \mathrm{K}$

Therefore, the condenser rejects $11.60 \mathrm{KW}$ of heat for every Kelvin rise in temperature of its surroundings.

III.4.6 Heat Rejection Factor, HRF
Recall (29): $\mathrm{HRF}=\frac{C_{C}}{C_{R}}=\frac{3260}{2893} 1.1269 \cong 1.13$

\section{III.5 Evaporator Design}

III.5.1 Evaporator capacity, $\mathrm{C}_{\mathrm{E}}$

Recall (16): $\quad \mathrm{C}_{\mathrm{E}}=M\left(h_{1}-h_{4}\right)=\mathrm{M} \mathrm{Q}_{41}$

Thus: $\mathrm{C}_{\mathrm{E}}=0.02 \times 140 \times 10^{3}=2800 \mathrm{~W}(\mathrm{~J} / \mathrm{s})$ or $2.8 \mathrm{KW}$

Also, the rated evaporator capacity, $C_{E \text { rated }}$

$$
\begin{aligned}
& =\frac{\text { Evaporator capacity }, C_{E}}{(\text { COP })_{\text {actual }}}=\frac{2800 \mathrm{~J} / \mathrm{s}}{2.03} \\
= & 1379.31 \mathrm{~W}(1.3793 \mathrm{KW} \text { or } 1.85 \mathrm{Hp})
\end{aligned}
$$

III.5.2 Evaporators' tube diameter

For the evaporator capacity of $2.8 \mathrm{KW}$, the following evaporator configurational parameters were selected:

Internal diameter, $\mathrm{d}_{\mathrm{EI}}=0.018 \mathrm{~m}$; Tube thickness, $\mathrm{t}_{\mathrm{E}}=$ $0.005 \mathrm{~m}$; External diameter, $\mathrm{d}_{\mathrm{E} 2}=0.017 \mathrm{~m}$; and Tube material $=$ Aluminum.

III.5.3 Surface Area of Evaporator, $\mathrm{A}_{\mathrm{E}}$ According to Rajput [14], $\mathrm{Q}=U A_{E} T_{D}=C_{C} \quad$ (20) Subject to (31): $A_{E}=\frac{C_{E}}{U T_{D}}=A_{n}$

But: $\quad \mathrm{Q}=2.8 \mathrm{KW}$ and $T_{D}=\left(t_{s}-t_{e}\right)$ where: $t_{s}=$ Coldest storage temperature $=-5^{\circ} \mathrm{C}$ (assumed) and $t_{e}=$ Lowest evaporating temperature $=-15^{\circ} \mathrm{C}$.

$$
\therefore \quad T_{D}=[-5-(-15)]=10^{\circ} \mathrm{C}(283 \mathrm{~K})
$$

Also, recall as before (22): $U=\frac{1}{\frac{r_{2}}{r_{1} h}+\frac{r_{2}}{K_{1}} \ln \frac{r_{2}}{r_{1}}}$

where: $r_{1}=\frac{d_{E 1}}{2}=\frac{0.018}{2}=0.009 \mathrm{~m} ; r_{2}=\frac{d_{E 2}}{2}=\frac{0.017}{2}$

$=0.0085 \mathrm{~m}$; and thermal conductivity of aluminum, $\mathrm{K}_{1}=$ $229 \mathrm{~W} / \mathrm{mK}$.

Conversely, to obtain the convective heat transfer coefficient of the evaporator, $\mathrm{h}$, the following fluid flow parameters were used:

i. The Reynold's number relationship (25) [14] with the thermal properties of $\mathrm{R} 134 \mathrm{a}$ at $-15^{\circ} \mathrm{C}$ (section III.1.2). Thus:

$$
\begin{aligned}
R_{e}=\frac{V d_{1} \rho}{\mu} & =\frac{0.508 \times 0.018 \times 13.271}{1.128 \times 10^{-5}} \\
& =\frac{0.121350024}{1.128 \times 10^{-5}}=10757.98
\end{aligned}
$$

Hence, with $R_{e}=10757.98$, the flow is turbulent. 
ii. Invoking Diltus-Boelter equation (24) for turbulency, the Nusselt parameter therefore becomes:

$$
N u=0.023 R_{e}{ }^{0.8} P_{r}^{n}
$$

But: $\mathrm{n}=0.4$ for heating fluid (see section II.5.1) and Prandtl number, $\mathrm{P}_{\mathrm{r}}=0.68$ (see section III.1.2) [14]. Thus:

$$
\begin{gathered}
\mathrm{Nu}=0.023(10757.98)^{0.8} \times(0.68)^{0.4} \\
=0.023(2680.29)(0.8570) \\
=33.12 \cong 33
\end{gathered}
$$

iii. Also, from (23), $N u=\frac{h d_{E 1}}{K}$

where: $\mathrm{K}=9.04810^{-3} \mathrm{~W} / \mathrm{mK}$ for $\mathrm{R} 134 \mathrm{a}$ at $-15^{\circ} \mathrm{C}$. Hence: $\mathrm{h}$ $=\frac{N u K}{d_{E 1}}=\frac{33 \times 9.048 \times 10^{-3}}{0.018}=\frac{0.298584}{0.018}$

$\therefore$ The convective heat transfer coefficient of the evaporator, $\mathrm{h}=16.588 \mathrm{~W} / \mathrm{m}^{2} \mathrm{~K}$. Thus:

The overall heat transfer coefficient of the evaporator,

$$
\begin{aligned}
& \mathrm{U}=\frac{1}{\left(\frac{0.0085}{0.009 \times 16.588}\right)+\frac{0.0085}{229} \ln \left(\frac{0.0085}{0.009}\right)} \\
& =\frac{1}{\left(\frac{0.0085}{0.149292}\right)+\frac{0.0085}{229} \ln \left(\frac{0.0085}{0.009}\right)} \\
& =\frac{1}{(0.056935401)+0.000037117 \ln (0.944444444)} \\
& 1 \\
& \overline{(0.056935401)+0.000037117(-0.057158414)} \\
& \frac{1}{0.056935401-0.000002121} \\
& \therefore \quad U=\frac{1}{0.05693328}=17.56 \mathrm{~W} / \mathrm{m}^{2} \mathrm{~K}
\end{aligned}
$$

Hence: the surface area of the evaporator,

$$
\mathrm{A}_{\mathrm{E}}=\frac{2800}{17.56 \times 283}=\frac{2800}{4969.48}=0.5634 \mathrm{~m}^{2}
$$

III.5.4 Length of the evaporator tubes, $\mathrm{L}_{\mathrm{E}}$

Recall (27): $A_{E}=\pi d_{E 1} L_{E}$

Hence: $L_{E}=\frac{A_{E}}{\pi d_{E 1}}=\frac{0.5634}{3.142 \times 0.018}=\frac{0.5634}{0.056556}=9.96 \mathrm{~m}$

III.5.5 Evaporator performance, $\mathrm{F}$

According to Andrew, et al [2], $C_{E}=F T_{D}$

Hence: $\quad \mathrm{F}=\frac{C_{E}}{T_{D}}=\frac{2800}{283}=9.89 \mathrm{KW} / \mathrm{K}$

Therefore, the evaporator is capable of absorbing $9.89 \mathrm{KW}$ of heat for every Kelvin rise in temperature of its surroundings.

\section{III.6 Liquid Receiver Size}

ISSN: 2250-3021
This receiver is cylindrical in shape and is capable of storing the entire refrigerant for any change in the system. To determine the volume $V_{R}$, the cross sectional diameter, $d_{R}$ of the receiver tank was considered as given in (30a) and (30b), respectively.

$$
\begin{aligned}
& \text { Thus: } \quad V_{R}=\frac{\pi d_{C 1}^{2} L_{C}}{4}+\frac{\pi d_{E 1}{ }^{2} L_{E}}{4} \\
& =\frac{\pi(0.015)^{2}(74.35)}{4 \quad}+\frac{\pi(0.018)^{2}(9.96)}{4}=0.01314+0.00253 \\
& \therefore \quad V_{R}=0.01567 \cong 0.0157 \mathrm{~m}^{3}
\end{aligned}
$$

But: $\quad V_{R}=\frac{\pi d_{R}^{2} L_{R}}{4}$

Thus: $\quad d_{R}{ }^{2}=\frac{4 V_{R}}{\pi L_{R}}$ where: $L_{R}=2 \mathrm{ft}=0.6096 \mathrm{~m}$ as standard receiver (Oral report from the vendors).

Hence: $\quad d_{R}{ }^{2}=\frac{4 \times 0.0157}{\pi \times 0.6096}=\frac{0.0628}{3.142 \times 0.6096}$

$$
\begin{aligned}
& =\frac{0.0628}{1.9154}=0.0328 \\
& \therefore \quad d_{R}=0.1811 \mathrm{~m}
\end{aligned}
$$

III.7 The Cold Room Designed and the Component Parts

The schematic diagram of the entire cold room designed and its components are as presented in Fig.5.

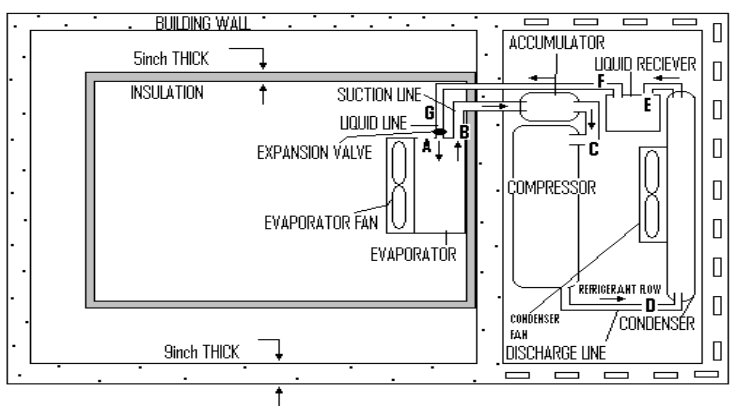

Fig.5: Schematic diagram of the cold room, indicating the component parts and the direction of refrigerant flow in them.

At Point A: The liquid refrigerant (R134a) enters the evaporator with very low pressure and temperature. At Point B: Vaporization of the refrigerant takes place. Here, the low pressure and temperature vapour refrigerant leaves the evaporator and enters into the compressor. At Point C: Superheated low temperature and pressure vapour refrigerant is sucked into the compressor. At point $D$ : Compressed vapour leaves the compressor and enters the condenser at high pressure and temperature. At point $\mathbf{E}$ : Sub cooled liquid refrigerant leaves the condenser and enters the liquid receiver. At Point $\mathbf{F}$ and G: The liquid refrigerant leaves the receiver and enters the thermostatic expansion value. 
III.7.1 Component parts used and choice of refrigerant

i. Compressor: The compressor type selected is the hermetic reciprocating compressor of $1 \mathrm{Hp}$ capacity; operating between suction pressure of $343 \mathrm{KPa}$ and discharge pressure of $955 \mathrm{KPa}$ for the whole cold room system. With the control aid of a system of thermostat, the compressor is switched on or off automatically depending on the load requirement. The compressor was chosen considering the comparatively low specific volume of $\mathrm{R} 134 \mathrm{a}$, its large pressure differential and the ease of repair and servicing.

ii. Evaporator: The type of evaporator selected is a bare tube coil, forced connection, dry expansion; and made of aluminum material. It is forced connection because air is forced over the coil by a fan, to increase heat transfer rate as well as distributing the cooling effect evenly round the room. The bare tube is chosen because of its relatively low cost due to ease of construction.

iii. Condenser: The condenser selected is a base mounted, forced convection, air cooled condenser made of copper material. It lies on the same base with the compressor. With the aid of the thermostatic system, the air-blowing fan switches off when heat load is low and switches on when heat load is high. This helps the air in circulation cool the refrigerant efficiently.

iv. Choice of Refrigerant: The refrigerant, R134a was selected for the following reasons: It is an almost odourless liquid with a low boiling point of $-26^{\circ} \mathrm{c}$ at atmospheric pressure. It has low specific volume of vapour with a good volumetric efficiency. It is non-toxic, non-corrosive, nonirritating and non-flammable. Its ozone depletion potential is zero with a little global warming potential. More importantly, its cost is comparatively low, and it produces relatively good refrigerating effect at moderate and economical operating condition. Also, its leakage can be easily detected by soap solution.

\section{III.7.2 Cost estimation of the component parts}

Table 6 presents the bill of quantities of the component parts and materials used for the design with their corresponding cost estimation at the prevailing market prices. The labour cost as in the Table, is the hour-charge per day for the building, construction and/or erection of the cold room and for the installation or mounting of the component parts in terms of the workmanship. Hence, the cost of erecting the cold room to finish entailed the cost of materials and the workmanship assuming the storage room was actually constructed. Thus:

$$
\begin{gathered}
\text { Total cost }=\text { material cost }+ \text { workmanship } \\
=\$ 547,703.50+\$ 85,000.00=\$ 632,703.50
\end{gathered}
$$

However, the amount excluded the cost of transportation and other miscellaneous expenses incurred. Based on these, an overhead cost of about $30 \%$ was estimated which brought the final cost to:

$$
\begin{gathered}
\# 632,703.50+(0.3 \times \$ 632,703.50) \\
=\# 632,703.50+\$ 189,811.05=\$ 822,514.55
\end{gathered}
$$

Thus, the cold room at the period would have taken only eight hundred and twenty-two thousand, five hundred and fourteen naira, and fifty-five kobo to be provided at the designed location in Umudike.

\section{III.7.3 Economics of the design}

The economics of this design was relative to that of an already installed cold room of the same capacity of condensing unit. This design thus was closely compared comparatively with an already existing traditional $4 \mathrm{Hp}$ capacity commercial cold room in Aba, a commercial hub and suburb town, near Umuahia city-centre, in Abia State; and the following similarities as presented in Table 7 were drawn.

Although the design as observed from the table compared favourably well, the slight difference in the condenser and the evaporator tube diameters and lengths as evident however, may be due to the differences in design locations and parameters such as temperature, pressure and refrigeration load. From the comparison, it was obvious that both have the same power input but the volume of this present design is greater than that of the traditional $4 \mathrm{Hp}$ capacity cold room.

Also, the cost of materials considered for use in the construction of this design may not increase so much the initial cost, since the cold room is on the same square area. There is an added advantage since the increase in volume of the cold room can accommodate more products and hence more income returns.

Moreover, the cold room was designed to be mounted on a concrete platform which greatly reduces the heat gain from the soil. The exclusion of floor insulation was justified in this design in order to minimize both material cost and hence, cost of construction. Also the traditional $4 \mathrm{Hp}$ capacity cold room is prone to ozone depletion due to usage of R12, while this design has zero ozone depletion potential by the use of R134a. Thus, this design is recommendable for modern cold room erection anywhere no matter the climatic or geographic location. 
IOSR Journal of Engineering

May. 2012, Vol. 2(5) pp: 1234-1250

Table 6: Cost Estimation of the Component Parts

\begin{tabular}{|c|c|c|c|}
\hline $\mathbf{S} / \mathbf{N}$ & Components & Quantity Description & N (Naira) \\
\hline \multicolumn{4}{|c|}{ (a) Material cost (If procured then) } \\
\hline 1 & $\begin{array}{c}\text { 4Hp condensing unit } \\
\text { (compressor + condenser + liquid receiver) }\end{array}$ & ( & 75,000 \\
\hline 2 & Evaporator & Type K6, L180 & 120,000 \\
\hline 3 & Thermostatic expansion & 4 tonne orifice & 12,000 \\
\hline 4 & Aluminum sheet & $\begin{array}{c}\text { A sheet of } 4.6 \mathrm{~m} \times 3 \mathrm{~m} \times 2.7 \mathrm{~m} \\
\text { Total outer surface area of room }=68.64 \mathrm{~m}^{2} \\
\text { Total inner surface area of room }=29.19 \mathrm{~m}^{2} \\
\text { Number of sheets }=68.64 \mathrm{~m}^{2}+29.19 \mathrm{~m}^{2}=97.83 \mathrm{~m}^{2} \\
\text { Total cost @ } 1,250.00 \text { per sheet }=97.83 \times 1250\end{array}$ & $122,287.50$ \\
\hline 5 & Polyurethane + foam & $\begin{array}{c}\text { A size area of } 4.6 \mathrm{~m} \times 3 \mathrm{~m} \times 2.7 \mathrm{~m}=\$ 1,900.00 \\
\text { Total area of insulation }=68.64 \mathrm{~m}^{2} \\
\text { Cost of polyurethane }+ \text { foam } \\
¥ 1,900.00 \times 68.64\end{array}$ & $130,416.00$ \\
\hline 6 & Floor material (mild steel plate) & $\begin{array}{c}\text { A plate of size } 2.4 \mathrm{~m} \times 1.2 \mathrm{~m} \times 0.003 \mathrm{~m}=\$ 8,000.00 \\
\text { Floor area }=7.508 \times 3.908=29,34 \mathrm{~m}^{2} \\
\text { No of plates }=(29.34) /(2.4 \times 1.2)=11 \\
\text { Total cost of steel plates }=11 \times 8,000.00\end{array}$ & $88,000.00$ \\
\hline \multicolumn{3}{|c|}{ Total } & $\mathbf{5 4 7 , 7 0 3 . 5 0}$ \\
\hline \multicolumn{4}{|c|}{ (b) Labour cost: Construction and installation (If erected then) } \\
\hline 7 & Building/construction of room & Workmanship & $15,000.00$ \\
\hline 8 & Installation of components & Workmanship & $70,000.00$ \\
\hline \multicolumn{3}{|c|}{ Total } & $85,000.00$ \\
\hline \multicolumn{3}{|c|}{ Grand total } & 632,703.50 \\
\hline
\end{tabular}

Table 7: Economics of the Design (Comparative Analysis)

\begin{tabular}{|c|c|c|c|}
\hline $\mathbf{S} / \mathbf{N}$ & Description of Components & Present Design & $\begin{array}{l}\text { 4Hp Cold Room } \\
\text { (Traditional 4Hp Capacity) in Existence }\end{array}$ \\
\hline 1 & Condensing unit & 4Hp capacity & Same \\
\hline \multirow{4}{*}{2} & \multicolumn{3}{|c|}{ Condenser tube } \\
\hline & Diameter (O.D) & $0.017 \mathrm{~m}$ & $0.015 \mathrm{~m}$ \\
\hline & Length & $247.91 \mathrm{~m}$ & $207.5 \mathrm{~m}$ \\
\hline & Material & Copper & Same \\
\hline \multirow{4}{*}{3} & \multicolumn{3}{|c|}{ Evaporator } \\
\hline & Diameter (OD) & $0.017 \mathrm{~m}$ & $0.016 \mathrm{~m}$ \\
\hline & Length & $0.265 \mathrm{~m}$ & $0.205 \mathrm{~m}$ \\
\hline & Material & Aluminum & Same \\
\hline \multirow{4}{*}{4} & \multicolumn{3}{|c|}{ Room size (Inside dimensions) } \\
\hline & Length & $4.6 \mathrm{~m}$ & $3.5 \mathrm{~m}$ \\
\hline & Width & $3 \mathrm{~m}$ & $2.5 \mathrm{~m}$ \\
\hline & Height & $2.7 \mathrm{~m}$ & $1.5 \mathrm{~m}$ \\
\hline 5 & Room outer and inner material & Aluminum & Same \\
\hline 6 & Wall insulation material & Polyurethane foam & $\begin{array}{l}\text { Polystyrene foam } \\
\end{array}$ \\
\hline 7 & Floor insulation & Nil: Floor mounted on concrete platform & $\begin{array}{l}\text { Floor thinly insulated and room also mounted on } \\
\text { concrete platform }\end{array}$ \\
\hline 8 & Refrigerant & R-134a & $\mathrm{R}-12$ \\
\hline 9 & Expansion device & Thermostatic expansion valve & Same \\
\hline \multirow{3}{*}{10} & \multicolumn{3}{|c|}{ Liquid receiver } \\
\hline & Length & $0.6 \mathrm{~m}$ & $0.6 \mathrm{~m}$ \\
\hline & Diameter $(\mathrm{OD})$ & $0.305 \mathrm{~m}$ & $0.25 \mathrm{~m}$ \\
\hline 11 & Location of the design & Umudike, Umuahia, Abia State & Aba, Abia State \\
\hline
\end{tabular}

\section{CONCLUSION}

A cold storage room for Umudike community and her environs has been designed. The cold room has an estimated total refrigeration capacity of $0.82 \mathrm{TR}$ (about
4Hp), and a maximum COP of 6.09. Its operating ambient temperature is $36^{\circ} \mathrm{C}$ with a rated evaporator capacity of $1.85 \mathrm{Hp}$ and a rated condenser capacity of $2.15 \mathrm{Hp}$, respectively. The cold room as designed compared 
favourably well within the limits of an already manufactured and traditionally erected commercial one of the same condensing capacity. This inevitably eliminated every doubt of its feasibility, commercialization and viability if erected. Hence, the objective of the design has been justified and achieved. It is thus, highly recommended for fabrication, construction and commercialization.

\section{RECOMMENDATION}

Installation of any cold room entails proper assembling of all refrigeration component parts with regards to the design specifications. Hence, it is recommended that these design specifications should be inculcated and followed as failure to meet up the desired specifications during installation leads to poor performance of the system.

During installation, the cold room, and its component parts should be properly leveled and aligned on the concrete platform to avoid any imbalance that might cause unwanted sound and vibration. Also, a cold room should not be installed close to any power generators, boilers, radiators, or any other heat generating machinery.

The evaporator should be installed inside the room on the wall at the width end, directly opposite the door end, whereas the condensing unit is to be installed on the base at the outside end, behind the evaporator wall. Moreover, vibration of the compressor should be avoided by mounting it on vibrating dampers.

As it relates to maintenance and operation, reliability and durability, adequate maintenance practice should be carried out on the cold room regularly to enhance its efficient performance. In this regard, preventive and predictive maintenance seem to be more adequate and suitable for the cold storage system.

Operators should be given proper training on the job so as to have knowledge of some repairs; and failure analysis chart of some critical equipment such as the compressor and the expansion valves should be provided on the equipment to assist the operators and the cold room personnel in case of any failure.

Consequently, it has been observed that direct heat from the sun's radiation increases the rate of heat infiltration into the room. To reduce this, an open shade (roofed only) should be built over the area where the cold room is installed. Further, the liquid line, running from the condenser to the expansion valves should be properly installed to prevent outside heat from flowing into the liquid.

Finally, the cold room should be mounted on a concrete platform that is at least $30 \mathrm{~cm}$ high from the ground level.

\section{ACKNOWLEDGEMENTS}

The authors acknowledge highly the efforts made by Charles Nwosu of the Department of Mechanical Engineering, Michael Okpara University of Agriculture, Umudike, Umuahia, Abia State for providing useful data and relevant information for the study which helped in the analyses.

\section{REFERENCES}

[1] J. Raynor, Basic Engineering Thermodynamics, Educational Low- Priced Books Scheme (ELBS), $5^{\text {th }}$ Edition, Longman Publishers, 1996.

[2] D.A. Andrew, H.T. Carl, F.B. Alfred, Modern Refrigeration and Air-conditioning, The Good Heart Wilcox Company Inc; 1988.

[3] G.H. Chukwu, C. Oriaku, A.H. Omar, K.C. Emeasor, A.D. Asiegbu, Hydrological Growth Season (HGS) for Umudike Agro-Belt of South Eastern Nigeria, Medwell Online Journal of Earth Sciences 1 (2): 93 97, 2007.

[4] O.S. Avrind, An Overview of Cold Storage Practice in India, Taraporeva, D.B. Sons \& Co. Private Limited Company, 1967.

[5] A.J. Rydzewski, W.R. Warren, Mechanical Refrigeration, McGraw-Hill International Revised $10^{\text {th }}$ Edition, 1996.

[6] Internet Google, Brief History of Refrigeration, http://www.probnewer.com/.../historyphp.html.

[7] National Population Commission, Population Census Data, Umuahia, Abia State 2007 Year Book, pp. 7 - 9, 2007.

[8] Michael Okpara University of Agriculture, Umudike, The Draft Master Plan Report, Somieb Consortium Enugu, Nigeria, 2004.

[9] National Root Crop Research Institute, Agrometerological Unit, NRCRI, Umudike, Umuahia, Abia State, 2004.

[10] National Root Crop Research Institute, Agrometerological Unit, NRCRI, Umudike, Umuahia, Abia State, 2008.

[11] C.P. Arora, Refrigeration and Air-conditioning, $2^{\text {nd }}$ Edition, Tata McGraw-Hill Publishing Company Limited, New Delhi, 2000.

[12] C.W. William, M.J. William, Refrigeration and Airconditioning Technology, An International Thompson Publishing Company, Delmar Publishers, 1995.

[13] P.A. Edwin, Refrigeration and Air- conditioning Guide - II: Commercial Refrigeration, Taraporevala, D.B. Sons \& Co. Private Limited, 1967.

[14] R.K. Rajput, Heat and Mass Transfer, $3^{\text {rd }}$ Edition, S. Chand \& Company Limited, Ram Nagar, New Delhi, 2006.

[15] A.A. Eugene, Mark's Standard Hand Book for Mechanical Engineers, $10^{\text {th }}$ Edition, 1997.

[16] P. Robert, American Society of Heating, Refrigerating \& Air-conditioning Hand Book, 1996. 